\title{
Mathematical models to describe the growth curves of white-egg layers
}

\section{Modelos matemáticos para descrever curvas de crescimento de poedeiras leves}

\author{
Cleber Franklin Santos de Oliveira ${ }^{1 *}$; João Marcos Novais Tavares²; Gerusa \\ da Silva Salles Corrêa ${ }^{3}$; Bruno Serpa Vieira ${ }^{4}$; Silvana Alves Pedrozo Vitalino \\ Barbosa $^{5}$; André Brito Corrêa ${ }^{3}$; Cristina Amorim Ribeiro de Lima ${ }^{6}$
}

\begin{abstract}
The aim of this study was to compare mathematical models describing growth curves of white-egg layers at different population densities. To fit the models, 4,000 growing white-egg layers were utilized. The experimental design was completely randomized, with population densities of $71,68,65,62$, and 59 birds per cage in the starter phase and 19, 17, 15, 13, and 11 birds per cage in the grower phase, with 10 replicates each. Birds were weighed weekly to determine the average body weight and the weight gain. Gompertz and Logistic models were utilized to estimate their growth. The data analysis was carried out using the PROC NLMIXED procedure of the SAS ${ }^{\circledR}$ statistical computer software to estimate the parameters of the equation because mixed models were employed. The mean squared error, the coefficient of determination, and Akaike's information criterion were used to evaluate the quality of fit of the models. The studied models converged for the description of the growth of the birds at the different densities studied, showing that they were appropriate for estimating the growth of whiteegg layers housed at different population densities. The Gompertz model showed a better fit than the Logistic model.
\end{abstract}

Key words: Gompertz. Performance. Poultry.

\section{Resumo}

Esta pesquisa teve por objetivo comparar modelos matemáticos para descrever curva de crescimento de poedeiras leves em diferentes densidades populacional, por meio de equações de modelos de crescimento. Para o ajuste dos modelos foram utilizadas 4000 poedeiras leves em crescimento. O delineamento utilizado foi o inteiramente casualizado nas densidades populacional de 71, 68, 65, 62 e 59 aves por gaiola na fase de cria e de 19,17, 15, 13 e 11 aves por gaiola na fase de recria, com dez repetições cada. Semanalmente, as aves foram pesadas para determinação do peso corporal médio e o ganho de peso. Para estimar o crescimento das aves foram utilizados os modelos de Gompertz e Logistic. A análise

Pesquisador, Universidade Federal de Mato Grosso, UFMT, Campus Cuiabá, MT, Brasil. E-mail: c_f_s_o@hotmail.com;

2 Discente de Mestrado, Programa de Pós-Graduação em Ciência Animal, UFMT, Campus Cuiabá, MT, Brasil. E-mail: tavares. jmn@gmail.com

3 Profs., UFMT, Campus Cuiabá, MT, Brasil. E-mail: gerusacorrea@hotmail.com; andrecorreaufmt@hotmail.com

4 Discente de Doutorado, Programa de Pós-Graduação em Ciência Animal, UFMT, Campus Cuiabá, MT, Brasil. E-mail: vieirabs@ hotmail.com

5 Prof ${ }^{a}$, Instituto Federal de Mato Grosso, Campus São Vicente, MT, Brasil. E-mail: pedrozo.silvana@yahoo.com.br

6 Prof ${ }^{\text {a }}$, Universidade Federal Rural do Rio de Janeiro, UFRRJ, Campus Soropédica, RJ, Brasil. E-mail: criblima@terra.com.br

* Author for correspondence 
dos dados foi realizada pelo procedimento PROC NLMIXED do programa computacional estatístico SAS ${ }^{\circledR}$, para estimar os parâmetros da equação por se tratar de modelos mistos. O quadrático médio do erro, o coeficiente de determinação e o critério de informação de Akaike foram utilizados na avaliação da qualidade do ajuste dos modelos. Os modelos estudados atingiram a convergência para a descrição do crescimento das aves nas diferentes densidades estudadas, adequados para estimar o crescimento corporal das aves com alto grau de confiabilidade. Os modelos estimaram o crescimento de poedeiras leves, alojadas em diferentes densidades populacional, em que o modelo de Gompertz apresentou melhores ajustes em comparação ao Logistic.

Palavras-chave: Avicultura. Desempenho. Gompertz.

\section{Introduction}

The success of the commercial poultry business is increasingly dependent upon the adequacy of management practices and on monitoring the weight and uniformity of birds, which, if not addressed, can have a direct impact on performance and the production cycle of these animals.

The growth of birds can be influenced by several factors such as weight development, body fat, lean tissue, and genetics, thereby requiring the study of growth curves so that producers can understand how birds grow, making it possible to develop more adequate nutritional programs.

Studying the growth curve of animals through mathematical models has been shown to be a very useful tool in research (THOLON; QUEIROZ, 2009), allowing for a better evaluation of the population and planning of desirable changes through management and selection and the optimization of nutrition and feeding strategies (GOUS, 1998).

With regard to the need to achieve appropriate weight gains, the feeding management of birds is worthy of attention, given the direct influence of nutrient intake on weight gain. According to Hruby et al. (1994), by adopting mathematical models to estimate animal growth nutritionists can dynamically predict the requirements for amino acids, protein, and energy according to the growth rates of birds when formulating diets.

Mathematical modeling can be defined as an instrument to describe the development and growth of the carcass and of the parts that enable the analysis needed for the adoption of strategies that provide better performance, especially concerning the increase in weight gain and feed efficiency.

Thus, the objective of this study was to compare mathematical models to describe growth curves of white-egg layers at different population densities.

\section{Material and Methods}

The experiment was conducted at the Mantiqueira Farm experimental site, located in Primavera do Leste, MT, Brazil.

Birds of the Hy-line line were distributed in a completely randomized design, as follows: during the starter phase, 3,250 chicks aged 1 to 14 days, with an initial weight of $38 \mathrm{~g}$, were utilized at the densities of $71,68,65,62$, and 59 birds per cage; and during the grower phase, 750 pullets from 15 to 119 days of age, with an average initial weight of $110 \mathrm{~g}$, were used at the densities of $19,17,15,13$, and 11 birds per cage, with 10 replicates each. Birds were weighed weekly to determine the average body weight for the adjustment of the models.

Birds received their diet ad libitum, formulated to meet the nutritional requirements of each stage of development.

To estimate the growth of these birds, the Gompertz $\left(\mathrm{Yt}=\mathrm{Ae}^{\mathrm{eb}(-\mathrm{kt})}+\varepsilon \mathrm{ij}\right)$ and Logistic $\left(\mathrm{Y}_{\mathrm{t}}=\mathrm{A} /\right.$ $\left(1+\mathrm{be}^{(-\mathrm{kt})}+\varepsilon \mathrm{ij}\right)$ models were used, where: $\mathrm{Yt}$ is the body weight at age $\mathrm{t}$; $\mathrm{A}$ is the asymptotic weight when $t$ tends to infinite, interpreted as adult weight, 
final weight, or maximum theoretical weight of the animal; $b$ is the constant of the integration without biological interpretation established by the initial values of $y$ and $t$ adjusted for situations in which $\mathrm{y}=0$ and/or $\mathrm{t}=0 ; \mathrm{k}$ is the rate at which the logarithmic function of the weight changes linearly per time unit, considered as a maturity index representing the relative rate at which $\mathrm{A}$ is reached, with $\mathrm{k}$ interpreted biologically as the growth average or the gain speed (BRACCINI NETO et al., 1996); and cij is the error associated with each observation.

The mean squared error, the coefficient of determination, and Akaike's information criterion were utilized in the evaluation of the quality of fit of the models. According to Santana et al. (2016), the mean squared error (MSE) was obtained by the equation $M S E=\frac{\operatorname{SSE}(\theta)}{n-p}$, where SSE is the sum of squared errors, $n$ is the number of observations, $p$ is the number of parameters of the model, and $\theta$ is the vector of the estimates of the parameters of the models. The MSE expresses the residual variance originating from the adjustment of the model in question, and in the comparison of various models, the lower its value, the more adequate the model is. The coefficient of determination $\left(\mathrm{R}^{2}\right)$ is given by, $R^{2}=1-\frac{\operatorname{SSE}(\theta)}{T S S}$, where TSS is the total sum of squares corrected by the mean, i.e., $=\sum_{i-1}^{n}(y-\hat{y})$, where $y$ is the observed value of the total weight from observation $i$; and $\hat{y}$ is the estimated value of the total weight from observation $i$ for a given model (SANTANA, 2013). Akaike's information criterion is a measure of quality of fit that estimates the expected value of the Kullback-Leibler (KL) information through $\mathrm{AIC}=-2 \mathrm{l}(\Theta)+2 \mathrm{P}$, where 1 is the likelihood of the model in question, is the vector of parameters, and $\mathrm{P}$ is the number of independent parameters of the model (AKAIKE, 1974). A low value for AIC is considered as representative of a better fit, and, in the selection of models, one should aim for the minimization of AIC.

The data analysis was carried out through the PROC NLMIXED procedure of SAS ${ }^{\circledR}$ statistical computer software, considering a mixed model.

\section{Results and Discussion}

The Gompertz and Logistic models converged for the description of growth at the different densities studied, which enables the use of the parameters of the functions as an estimate of the growth and maturity of the animals. According to Gous et al. (1999), the adjustment of a model fitted to the growth curve of animals is the first step in the prediction of nutritional requirements of different genotypes, allowing their inclusion in genetic breeding programs. The estimated values for average weight at maturity, maturity rate, and the respective adjustments are shown in Table 1.

Table 1. Parameter estimates of Gompertz and Logistic equations, the coefficient of determination $\left(\mathrm{R}^{2}\right)$, mean square error (MSE) and the criterion of Akaik (AIC) to live weight at different densities.

\begin{tabular}{cccccccc}
\hline & \multirow{2}{*}{ Densities } & \multicolumn{3}{c}{ Parameter } & \multicolumn{3}{c}{ Adjustment } \\
\cline { 2 - 7 } & & $\mathrm{WM}(\mathrm{g})$ & $\mathrm{k}$ (per day) & $\mathrm{t}$ (days) & $\mathrm{R}^{2}$ & MSE & AIC \\
\hline \multirow{6}{*}{ Gompertz } & D1 & 1385 & 0,02 & 54 & 0,999 & 47,593 & 9,45 \\
& D2 & 1362 & 0,02 & 53 & 0,999 & 44,238 & 9,38 \\
& D3 & 1399 & 0,02 & 54 & 0,999 & 43,304 & 9,36 \\
& D4 & 1383 & 0,02 & 53 & 0,999 & 44,243 & 9,38 \\
& D5 & 1381 & 0,02 & 52 & 0,999 & 50,806 & 9,52 \\
\hline
\end{tabular}


continuation

\begin{tabular}{llllllll}
\hline \multirow{4}{*}{ Logistic } & D1 & 1095 & 0,05 & 57 & 0,995 & 94,215 & 10,14 \\
& D2 & 1085 & 0,05 & 57 & 0,995 & 84,389 & 10,11 \\
& D3 & 1104 & 0,05 & 57 & 0,995 & 88,796 & 10,08 \\
& D4 & 1104 & 0,05 & 57 & 0,995 & 91,413 & 10,11 \\
& D5 & 1115 & 0,05 & 56 & 0,995 & 102,468 & 10,22 \\
\hline
\end{tabular}

$\mathrm{WM}=$ weight at maturity; $\mathrm{k}=$ maturity rate $\mathrm{t}=$ time when maturity is maximum.

The asymptotic weight, or weight at maturity (WM), of the birds varied with the density and the model utilized, according to the criteria used to evaluate the quality of fit of the model i.e. the mean squared error (MSE), the coefficient of determination $\left(\mathrm{R}^{2}\right)$, and Akaike's information criterion (AIC).

As discussed by Neme et al. (2006), it is important to note that because it is determined by a mathematical function, the weight at maturity (WM) of the birds approaches the weight recommended by the manuals for the start of the laying peak, indicating good assertiveness of the equations. In the current study, WM varied from 1.085 to 1.399 $\mathrm{kg}$ as a function of the density and model utilized.

Thus, the biological interpretation of the parameters, as a criterion in the evaluation of the growth curve models, allows us to summarize the growth characteristics of the population (initial weight, growth rate, and adult weight) into three or four parameters; to evaluate the profile of responses of treatments over time; to study the interactions of the responses of the sub-populations or treatments over time; and to detect, in a population, heavier animals at earlier ages (FREITAS, 2005; THOLON; QUEIROZ, 2009).

According to Bianchini et al. (2008), biological phenomena in animal development are quite complex, involving interactions among hormonal, nutritional, genetic, and metabolic factors, defined as an increase in size resulting from changes in the functional capacity of many organs and tissues of the animal that can occur from birth until the animal reaches its adult weight. This is illustrated in Figure 1, in which weight gain is more pronounced (acceleration phase) from the start of animal development until the individual reaches maturity or adult body weight, corresponding to a relatively constant linear growth rate; after this, there is a decline in growth rate, which approaches zero or is considered null.

Because the maturity rate $(\mathrm{k})$ represents the time required by the animal to achieve its maximum weight gain or asymptotic weight, the results demonstrate that because of the relatively small variation in weight at birth, the variation between $\mathrm{k}$ values represents precisely the variations in the relative speed at which the animal grows (MALHADO et al., 2009). Thus, in agreement with Sarmento et al. (2006) and Santana (2013), animals that present a lower growth rate tend to reach higher maturity weights, showing an inverse relationship between $\mathrm{Pm}$ and $\mathrm{k}$; this was shown in the current study, in which the birds that displayed a $\mathrm{k}$ of 0.02 $\mathrm{g} \mathrm{day}^{-1}$ had an average WM of $1.385 \mathrm{~kg}$, and birds with a $\mathrm{k}$ of $0.05 \mathrm{~g} \mathrm{day}^{-1}$ had an average WM of 1.100 $\mathrm{kg}$.

The inflection point $(\mathrm{t})$ was obtained by the first derivative of the mathematical models utilized as a function of increasing time until the maximum growth point was reached. This ranged from 51 to 54 days in the Gompertz model, in which animals reached a maximum growth rate of $12 \mathrm{~g}$, and from 56 to 57 days in the Logistic model, with a maximum growth rate of $13 \mathrm{~g}$. From this point, the growth rate shifted from increasing to decreasing, 
i.e., growth slowed until it became null when the birds reached maturity (Figure 2). According to Marcato (2007), the inflection point of the growth curve is a parameter of great economic interest that indicates the age at which birds present their maximum growth rate.
According to Neme et al. (2006), the maximum growth rate $(\mathrm{t})$ is named the inflection point of the growth curve, and it represents the exact moment when the growth rate shifts from increasing to decreasing, such that as the animals age, their growth rate decelerates and their weight gain decreases.

Figure 1. Growth curve adjusted to the average weight estimated by the models of Gompertz (-) and Logistic (- -).

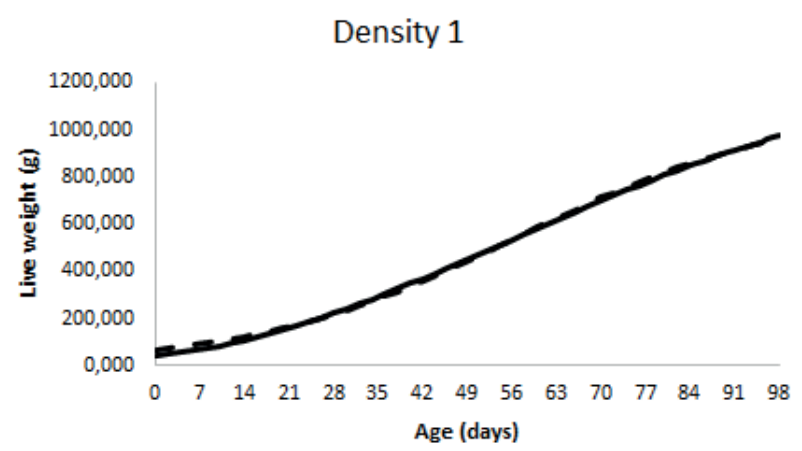

Density 3

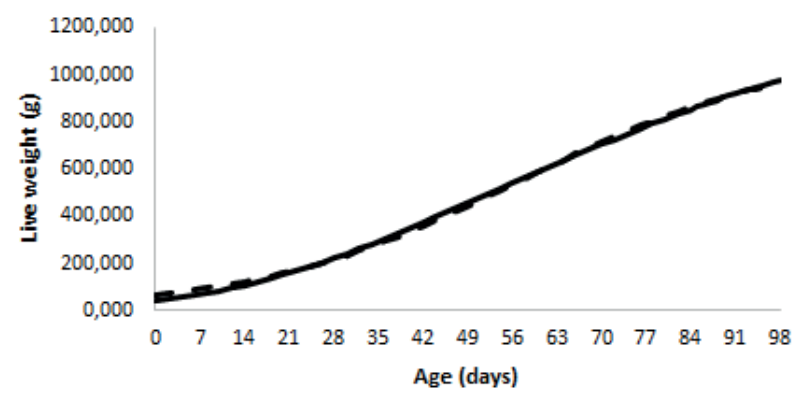

Density 5

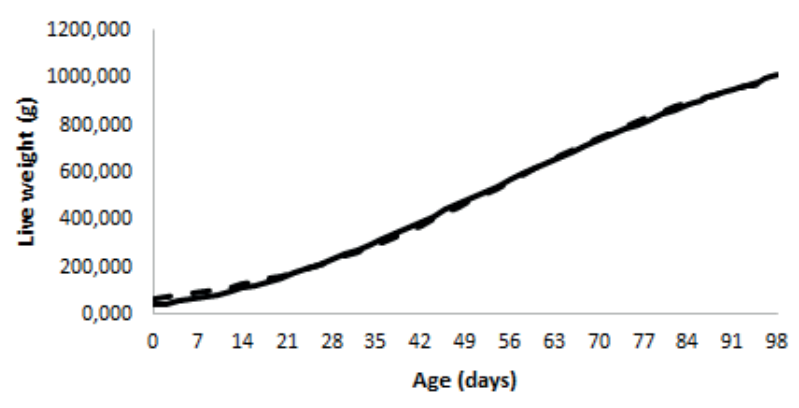

According to Longo (2000), from time " $t$ ", the growth rate shifts from rapid to slow with the advance of age, with lower weight or tissue gains every day. Thus, the growth-curve pattern changes from concave to convex.
Density 2

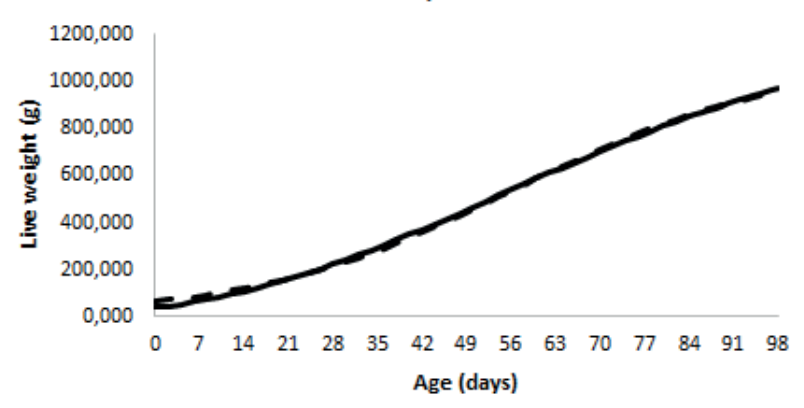

Density 4

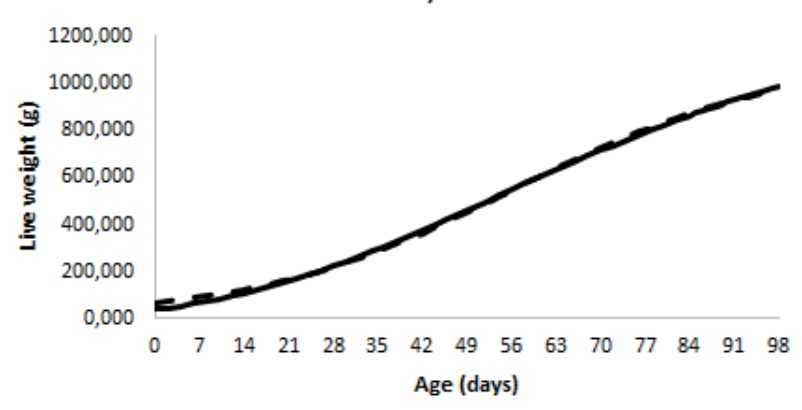

Validating the best model to evaluate the quality of fit of the equations is not an easy task, since different evaluators have been proposed in the literature, and each one recommends a certain trait, such as minimization of errors of fit, prediction 
ability, and simplicity of the model (SILVEIRA et al., 2011).

The coefficient of determination $\left(\mathrm{R}^{2}\right)$, one of the evaluation criteria, expresses the proportion of the total variation observed in the sample data, indicating how much of the total variation is explained by the model. Low values indicate a poor fit, whereas high values show that the model gives an excellent fit. $\mathrm{R}^{2}$ expresses the proportion of the total variation observed in the sample data that is explained by the adjusted model. In the current study the Gompertz model presented an $\mathrm{R}^{2}$ of 0.999, whereas in the Logistic model $\mathrm{R}^{2}$ was 0.995 , indicating the only difference between the models, which was not detected at the densities studied for this criterion.

Figure 2. Maturity rate and time to maturity and maximum estimated by the models of Gompertz (-) and Logistic (- -)
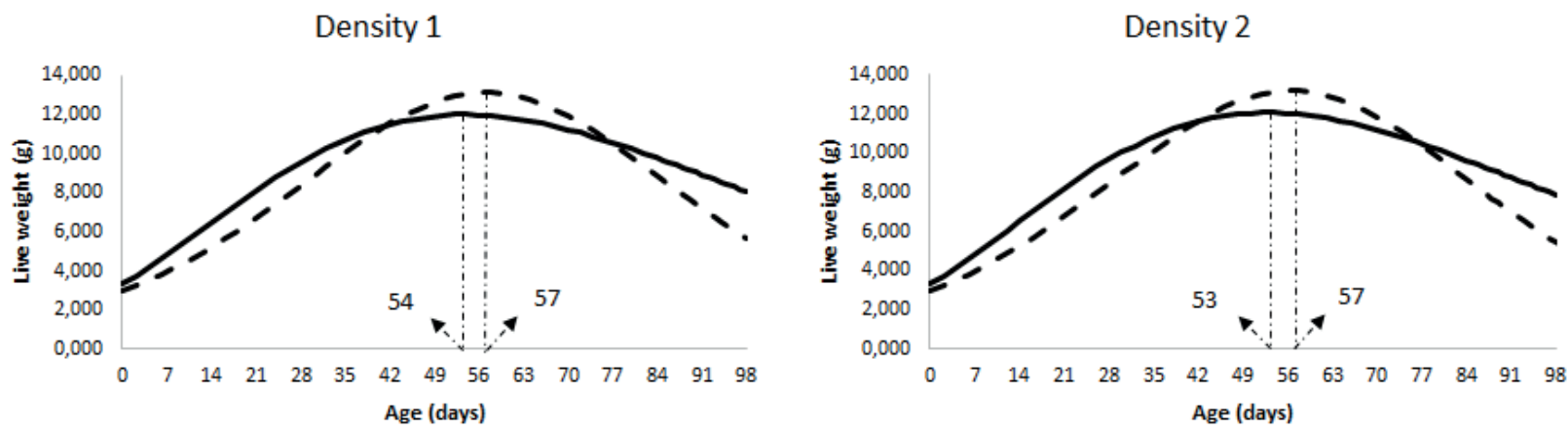

Density 3
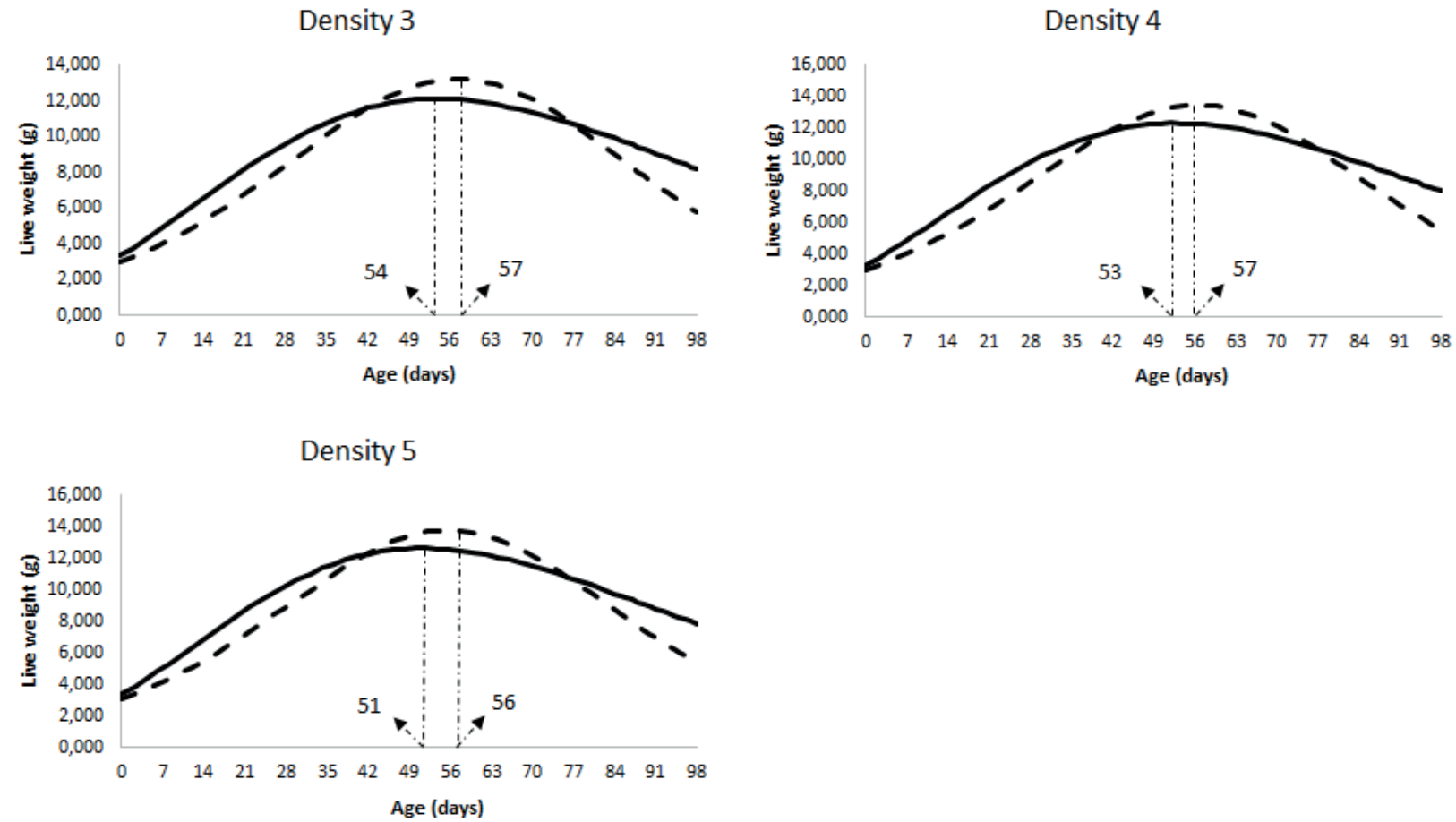
It was observed that the Gompertz model presented an $\mathrm{R}^{2}$ of 0.999 , whereas the Logistic model showed 0.995, indicating only difference between the models, which was not detected for the densities studied for this criterion.

The coefficients of determination were higher than $99 \%$, indicating that the growth of the animals was estimated adequately in the conditions of this study, and all functions showed an almost perfect fit, indicating that the studied models were suitable for estimating body growth from the weight/age data of the layers at different population densities, with a high degree of confidence.

The mean squared error, utilized as a criterion to compare models, expresses the residual variance originating from a model; the lower its value, the more adequate the evaluated model. In this regard, the Gompertz model showed lower values for MSE than the Logistic model. Considering the different densities within each model, density D3 showed the lowest MSE (43.304) in the Gompertz model, whereas with the Logistic model the estimated D2 was 84.389 .

With regards to Akaike's information criterion, the Gompertz model had a lower mean value than the Logistic model: 9.42 and 10.13, respectively. Within the Gompertz model, density D3 showed the lowest value for this criterion of evaluation of fit.

A lower value for Akaike's information criterion is considered to represent a better fit; thus, in the selection of models one should aim at its minimization. The logic of the test is that there is no hypothesis being tested as in the F test; on the contrary, it allows us to determine to what extent and which model is the most correct. The theoretical mathematical basis of this criterion is rather complex - it combines maximum likelihood theory, information theory, and the concept of information entropy (FLORIANO et al., 2006).

For the final comparison using statistical tools like the AIC, only the models that fit well to the data should be considered, and those that do not provide good results should be disregarded (MOTULSKY; CHRISTOPOULOS, 2003).

\section{Conclusion}

The models estimated the growth of white-egg layers housed at different population densities, with the Gompertz model showing a better fit than the Logistic model.

\section{References}

AKAIKE, H. A new look at the statistical model identification. IEEE Transactions Automomatic Control, v. 19, n. 6, p. $716-723,1974$.

BIANCHINI, W.; SILVEIRA, A. C.; ARRIGONI, M. B.; JORGE, A. M.; MARTINS, C. L.; RODRIGUES, É. Crescimento e características de carcaça de bovinos superprecoces Nelore, Simental e mestiços. Revista Brasileira de Saúde e Produção Animal, Salvador, v. 9, n. 3, p. 554-564, 2008.

BRACCINI NETO, J.; DIONELLO, N. J. L.; SILVEIRA JUNIOR, P.; BONGALHARDO, D. C.; XAVIER, E. G. Análise da curva de crescimento de aves de postura. Revista Brasileira de Zootecnia, Viçosa, MG, v. 25, n. 6, p. 1062-1073, 1996.

FLORIANO, E. P.; MULLER, I.; FINGER, C. A. G.; SCHNEIDER, P. R. Ajuste e seleção de modelos tradicionais para série temporal de dados de altura de árvores. Ciência Florestal, Santa Maria, v. 16, n. 2, p. 177-199, 2006.

FREITAS, A. R. Curvas de crescimento na produção animal. Revista Brasileira de Zootecnia, Viçosa, v.34 n.3, p.786-795, 2005

GOUS, R. M. Making progress in the nutrition of broilers. Poultry Science, Savoy, v. 77, n. 1, p. 111-117, 1998.

GOUS, R. M.; MORAN JUNIOR, E. T.; STILBORN, H. R.; BRADFORD, G. D.; EMMANS, G. C. Evaluation of the parameters needed to describe the overall growth, the chemical. growth, and the growth of feathers and breast muscles of broilers. Poultry Science, Savoy, v. 78, n. 6, p. 812-821, 1999.

HRUBY, M.; HAMRE, M. L.; COON, C. N. Growth modeling as a tool for predicting amino acid requirements of broilers. The Journal of Applied Poultry Research, Champaign, v. 3, n. 4, p. 403-415, 1994. 
LONGO, F. A. Estudo do metabolismo energético e do crescimento de frangos de corte. 2000. Dissertação (Mestrado em Zootecnia) - Universidade Estadual Paulista, Jaboticabal.

MALHADO, C. H. M.; CARNEIRO, P. L. S.; MARTINS FILHO, R.; PEREIRA, D. G.; AFFONSO, P. R. A. M.; AZEVEDO, D. M. M. R.; SOUZA, J. C. Parâmetros e tendência genética da taxa de maturação e peso assintótico de bovinos da raça Nelore no estado da Bahia. Revista Brasileira de Saúde e Produção Animal, Salvador, v. 10, n. 2, p. 245-255, 2009.

MARCATO, S. M. Características do crescimento corporal, dos órgãos e tecidos de duas linhagens comerciais de frangos de corte. 2007. Tese (Doutorado em Zootecnia) - Universidade Federal Paulista, Jaboticabal.

MOTULSKY, H.; CHRISTOPOULOS, A. Fitting models to biological data using linear and nonlinear regression: a practical guide to curve fitting. $4^{\text {th }}$ ed. San Diego: GraphPad Software, 2003. 351 p.

NEME, R.; SAKOMURA, N. K.; FUKAYAMA, E. H.; FREITAS, E. R.; FIALHO, F. B.; RESENDE, K. T.; FERNANDES, J. B. K. Curvas de crescimento e de deposição dos componentes corporais em aves de postura de diferentes linhagens. Revista Brasileira de Zootecnia, Viçosa, MG, v. 35, n. 3, p. 1091-1100, 2006.
SANTANA, T. J. S. Novos modelos de curva de crescimento par bovinos de corte. 2013. Tese (Doutorado em Estatística e Experimentação Agropecuária) Universidade Federal de Lavras, Lavras.

SANTANA, T. J. S.; SCALON, J. D.; BITTENCOURT, T. C. C.; SANTANA, A. S. A. Modelo von bertalanffy com resposta em platô para descrever curvas de crescimento de bovinos de corte. Revista Brasileira de Biometria, Lavras, v. 34, n. 4, p. 646-655, 2016.

SARMENTO, J. L. R.; REZAZZI, A. J.; SOUZA, W. H.; TORRES, R. A.; BREDA, F. C.; MENEZES, G. R. O. Estudo da curva de crescimento de ovinos Santa Inês. Revista Brasileira de Zootecnia, Viçosa, MG, v. 35, n. 2, p. 435-442, 2006.

SILVEIRA, F. G.; SILVA, F. F.; CARNEIRO, P. L. S.; MALHADO, C. H. M.; MUNIZ, J. A. Análise de agrupamento na seleção de modelos de regressão nãolineares para curvas de crescimento de ovinos cruzados. Ciência Rural, Santa Maria, v. 41, n. 4, p. 692-698, 2011.

THOLON, P.; QUEIROZ, S. A. Modelos matemáticos utilizados para descrever curvas de crescimento em aves aplicados ao melhoramento genético animal. Revista Ciência Rural, v. 39, n. 7, p. 2261-2269, 2009. 